\title{
SCENIC RIVERS ASSOCIATION V. LYNN: THE EFFECT OF NEPA ON THE INTERSTATE LAND SALES ACT
}

\section{INTRODUCTION}

By enacting the National Environmental Policy Act of $1969^{1}$ (NEPA), Congress sought to "provide all agencies and all Federal officials with a legislative mandate and a responsibility to consider the consequences of their actions on the environment."2 In addition to establishing a responsible national environmental policy for the federal government, NEPA was designed to facilitate the implementation of that policy by providing for the gathering of information about the environmental effects of federal actions. ${ }^{3}$ Under NEPA, federal agencies planning "major Federal actions significantly affecting the quality of the human environment"4 are required to prepare environmental impact

142 U.S.C. $\S \S 4321-47$ (1970). For an outstanding introduction to NEPA, see F. Anderson, NEPA in the Courts: A Legal Analysis of the National Environmental Policy Act (1973).

2 Comm. on Interior and Insular Affairs, Report on National Environmental Policy Act of 1969, S. Rep. No. 296, 91st Cong., 1st Sess. 14 (1969). See 115 Cong. Rec. 40416 (1969) (remarks of Senator Jackson).

${ }^{3}$ See Chapter V-Council on Environmental Quality Guidelines, 40 C.F.R. §§ 1500.1-1500.14 (1974).

${ }^{4}$ U.S.C. $\$ 4332(2)(C)$ (1970). Section 4332 reads in part as follows:

The Congress authorizes and directs that, to the fullest extent possible: (1) the policies, regulations, and public laws of the United States shall be interpreted and administered in accordance with the policies set forth in this chapter, and (2) all agencies of the Federal Government shall- . . .

(C) include in every recommendation or report on proposals for legislation and other major Federal actions significantly affecting the quality of the human environment, a detailed statement by the responsible official on-

(i) the environmental impact of the proposed action,

(ii) any adverse environmental effects which cannot be avoided should the proposal be implemented,

(iii) alternatives to the proposed action,

(iv) the relationship between local short-term uses of man's environment and the maintenance and enhancement of long-term productivity, and

(v) any irreversible and irretrievable commitments of resources which would be involved in the proposed action should it be implemented.

Prior to making any detailed statement, the responsible Federal official shall consult with and obtain the comments of any Federal agency which has jurisdiction by law or special expertise with respect to any environmental impact involved. Copies of such statement and the comments and views of the appropriate Federal, State, and local agencies, which are authorized to develop and 
statements. The intended scope of NEPA is made plain in the Act itself: "[T]o the fullest extent possible . . . the policies, regulations and public laws of the United States shall be interpreted and administered in accordance with the policies set forth in [NEPA]."5

Passage of the Act spawned great hopes, ${ }^{6}$ drew substantial criticism, ${ }^{7}$ and generated a great volume of litigation. ${ }^{8}$ Not surprisingly, the bulk of the NEPA litigation has arisen from attempts to forestall a federal agency from taking action or carrying out a project until an environmental impact statement has been filed.

It is the purpose of this Comment to examine the operation of NEPA in areas of limited federal involvement, specifically the administration of the Interstate Land Sales $\mathrm{Act}^{9}$ (ILSA) by the Department of Housing and Urban Development (HUD). ILSA requires that real estate developers who plan to sell subdivisions of more than fifty lots in interstate commerce file a "statement of record" 10 with the Secretary of HUD. The obvious goal of the registration statement is the complete and accurate disclosure of information that would help a prospective real estate purchaser make an informed decision. "The purpose of full disclosure is to deter or prohibit the sale of land by use of the mails or other channels of interstate commerce through misrepresentation of material facts relating to the property." 1 The statement becomes effective no later than thirty days after filing ${ }^{12}$ unless the Secre-

enforce environmental standards, shall be made available to the President, the Council on Environmental Quality and to the public as provided by section 552 of Title 5, and shall accompany the proposal through the existing agency review processes....

542 U.S.C. $\S 4332$ (1970) (emphasis supplied).

${ }^{6}$ Hanks \& Hanks, An Environmental Bill of Rights: The Citizen Suit and the National Environmental Policy Act of 1969, 24 Rutgers L. REv. 230 (1970).

${ }^{7}$ E.g., Murphy, The National Environmental Policy Act and the Licensing Process: Environmentalist Magna Carta or Agency Coup de Grace?, 72 Colum. L. REv. 963 (1970); Sax, The (Unhappy) Truth about NEPA, 26 OKLA. L. Rev. 239 (1973).

${ }^{8}$ See F. ANDERSON, supra note 1 , at 298-307.

9 15 U.S.C. $\$ \$ 1701-20$ (1970).

1015 U.S.C. $\$ 1705(1970)$.

${ }^{11}$ Conf. Rep. No. 1785, 90 th Cong., 2d Sess. (1968), in 1968 U.S. Code Cong. \& Ad. News 3053, 3066. Comparison of the Interstate Land Sales Act and the Securities Act of 1933,15 U.S.C. $\$ \S 77$ a-aa (1970), reveals remarkable similarities. "This "truth in securities' law has two basic objectives: (a) to provide investors with material financial and other information concerning securities offered for public sale; and (b) to prohibit misrepresentation, deceit and other fraudulent acts and practices in the sale of securities generally ...."W. Cary, Cases and Materials on Corporations A-79 (4th ed. 1969). 1215 U.S.C. $\& 1706$ (a) (1970). 
tary finds it to be "incomplete or inaccurate in any material respect,"13 and any material misstatement or omission subjects a developer to both civil and criminal liability. ${ }^{14}$

In the recent case of Scenic Rivers Association v. Lynn, ${ }^{15}$ the Court of Appeals for the Tenth Circuit affirmed an order requiring HUD to submit an environmental impact statement before permitting a real estate developer to complete sales under ILSA. The case stemmed from a proposed development by the Flint Ridge Development Company of seven thousand acres of land along the Illinois River, a "scenic river" by state designation. ${ }^{16}$ Sewage from the proposed three thousand lots and homes, the district court found, would eventually make its way into the Illinois River because of the porous nature of the area's soil. ${ }^{17}$ It was not difficult for the court to conclude that the development would significantly affect the quality of the environment.

The most salient aspect of the district court's decision was the holding that HUD's authority to suspend a disclosure statement for inaccuracies could constitute major federal action. The district court was of the view that any time a federal agency's action would advance a project that would have a significant environmental impact, the agency's action would be subject to application of NEPA. On appeal, the Tenth Circuit voiced substantial agreement with this interpretation:

[T] he consequences of the government's approval of the statement in terms of ease of obtaining funds and in terms of the ultimate direct consequences on the environment of the building of the houses lead to the conclusion that the district court was correct in holding that major federal action significantly affecting the quality of the human environment was present. ${ }^{18}$

The court, however, failed to address itself to the problem of the limited nature of HUD's authority under ILSA.

The primary statutory issue raised by the interaction of NEPA and ILSA is whether HUD's role in protecting purchasers

${ }^{13} 15$ U.S.C. $\$ 1706$ (b) (1970).

1415 U.S.C. $\$ \$ 1709,1717(1970)$.

15382 F. Supp. 69 (E.D. Okla. 1974), aff'd, Civil Nos. 74-1520 \& 74-1750 (10th Cir., July 30,1975$)$.

16382 F. Supp. at 73 .

${ }^{17} \mathrm{Id}$.

${ }^{18}$ Civil Nos. $74-1520$ \& $74-1750$ at 8. 
of real estate amounts to the major federal action that is a prerequisite to application of NEPA. This issue must be viewed in light of NEPA's broad mandate that the laws of the United States be interpreted and administered, "to the fullest extent possible," in accord with NEPA. The Scenic Rivers decision, in holding that HUD's activities under ILSA require compliance with NEPA, raises important questions about NEPA's impact on essentially private projects which only involve the activities of a federal agency tangentially.

\section{When an Impact Statement is Required}

\section{A. Major Federal Action}

Many difficulties are encountered in defining what Congress meant by the phrase "major Federal actions"19 in NEPA. Among the logical interpretations of the phrase are the following possibilities: The federal action must simply be financially large in scope, as when a project significantly affecting the environment stems from "major" federal funding; ${ }^{20}$ the federal ac-

1942 U.S.C. $\S 4332(2)(C)$ (1970).

${ }^{20}$ The federal government gives financial and planning support to state and local governments and to private organizations; in return for this assistance, it frequently demands some control over the project. But see note 49 infra \& accompanying text. Federal participation in state highway construction is the most fertile source of litigation within this category. See, e.g., Named Individual Members of the San Antonio Conservation Soc'y v. Texas Highway Dep't, 496 F.2d 1017 (5th Cir. 1974); Citizens for Balanced Environment \& Transp., Inc. v. Volpe, 376 F. Supp. 806 (D. Conn.), aff'd per curiam, 503 F.2d 601 (2d Cir. 1974); Scherr v. Volpe, 466 F.2d 1027 (7th Cir. 1972); Lathan v. Volpe, 455 F.2d 1111 (9th Cir. 1971).

Especially difficult are the cases in which a highway segment built solely with state funds would be of no use unless joined to a larger segment built with federal assistance. See Citizens for Balanced Environment \& Trans., Inc. v. Volpe, 376 F. Supp. 806, 813-14 (D. Conn.), aff'd per curiam, 503 F.2d 601 (2d Cir. 1974). Impact statements have been required even absent federal funding when the project was deemed to have a federal character because of close federal contacts. See, e.g., Sierra Club v. Volpe, 351 F. Supp. 1002 (N.D. Cal. 1972); La Raza Unida v. Volpe, 337 F. Supp. 221 (N.D. Cal. 197I), aff'd, 488 F.2d 559 (9th Cir. 1973), cert. denied before judgment of the Ninth Circuit, 409 U.S. 890 (1972) (federal action despite absence of application for federal funds). But see Ely v. Velde, 363 F. Supp. 277, 286 (E.D. Va. 1973) (project loses federal character when state waives use of federal funds).

A primary concern in this area seems to be that federal funds are being shifted to avoid preparation of an impact statement for segments that have unique and severe environmental consequences. Although the use of federal funds in a state project will generally result in a finding of federal action, Indian Lookout Alliance v. Volpe, 484 F.2d 11, 16 (8th Cir. 1973) (dictum), it has been held that the use of some federal planning funds in a large project does not result in "federal action" because the federal involvement is too small. James River \& Kanawha Canal Parks, Inc. v. Richmond Metropolitan Authority, 359 F. Supp. 611, 636 n.72 (E.D. Va.), aff'd per curiam, 481 F.2d 1280 (4th Cir. 1973). 
tion must involve the discretionary authority of a federal agency to approve or disapprove an environmentally significant project on environmental grounds; ${ }^{21}$ the federal action itself must substantially cause the significant environmental impact regardless of dollar output, as when the federal action directly produces the depletion of an important resource; ${ }^{22}$ the federal action must involve the authority of a federal agency to approve or disapprove an environmentally significant project (even on nonenvironmental grounds), as when inaccuracies appear in an ILSA disclosure statement. ${ }^{23}$ Each of these possible interpretations will be examined in turn.

It is tempting to view the degree of a federal agency's involvement in a project in terms of its financial expenditure. In Natural Resources Defense Council, Inc. v. Grant, ${ }^{24}$ for instance, the district court determined that major federal action existed because of "substantial planning, time, resources or expenditure." 25 That case involved a conservation and flood prevention project requiring sixty-six miles of "channel enlargement." 26 The project was to be financed by the state and federal governments at a cost of about $\$ 1.5$ million, the federal share being $\$ 706,000$. While deciding that there was "certainly"27 major federal action, the court failed to indicate the precise level at which the certainty arose.

Apart from the obvious difficulty of trying to define the

Federal interaction with private parties often involves housing and redevelopment projects. E.g., Hiram Clarke Civic Club v. Lynn, 476 F.2d 421 (5th Cir. 1973); San Francisco Tomorrow v. Romney, 472 F.2d 1021 (9th Cir. 1973). In Goose Hollow Foothills League v. Romney, 334 F. Supp. 877 (D. Ore. 1971), HUD made a commitment to lend more than three million dollars to the developer of a sixteen-story apartment building without preparing an impact statement. Further disbursement of federal money was enjoined until HUD filed an impact statement. And in Silva v. Romney, 473 F.2d 287 (1st Cir. 1973), a private developer of a housing project secured a mortgage guarantee and an interest grant from HUD. In an initial suit, HUD was ordered to supply an impact statement. While HUD was complying with this mandate, the developer proceeded with preliminary construction activities, such as tree cutting. In deciding that it could enjoin the private developer, the court said, citing Ivanhoe Irrigation District v. McCracken, 357 U.S. 275 (1958), that "one in partnership with the federal government can be prohibited from acting in a certain manner." 473 F.2d at 290.

${ }^{21}$ See text accompanying notes 28-32 infra.

${ }^{22}$ See text accompanying notes 33-42 infra.

${ }^{23}$ See text accompanying notes $43-49$ infra.

24341 F. Supp. 356 (E.D.N.C. 1972) (impact statement ordered), 355 F. Supp. 280 (E.D.N.C. 1973) (injunction issued pending full hearing on sufficiency of final statement); see also Citizens Organized to Defend Environment, Inc. v. Volpe, 353 F. Supp. 520, 540 (S.D. Ohio 1972).

25 341 F. Supp. at 366-67.

${ }^{26}$ Id. at 362.

${ }^{27} I d$. at 367 . 
minimum level of funding at which major federal action occurs, this quantitative approach cannot in itself satisfy the NEPA goal of creating federal responsiveness to qualitative environmental concerns. Some actions by federal agencies may require little planning, time, or resource expenditure, but still be crucial to an environmentally significant project. In Davis v. Morton, ${ }^{28}$ for instance, the Department of the Interior had the authority to evaluate the environmental impact of a ninety-nine-year lease of a substantial amount of restricted Indian land by the Pueblo Indians to a development company. The Department of the Interior could disapprove the leasing project on environmental grounds; ${ }^{29}$ yet in quantitative terms, the Department had no interest, stemming from financing or investment, in the leasing endeavor.

The decision in Davis $v$. Morton recognizes that NEPA requires federal agencies to act responsibly in the protection of the environment, because "where a federal license or permit is involved, or where Congress possesses and has utilized its plenary power of regulation ... federal approval constitutes major federal action." ${ }^{30}$ Thus, when a federal agency with "plenary" powers of regulation has the authority to avoid or reduce potentially significant environmental harm, NEPA should be viewed as placing a legal obligation upon that agency to prepare an impact statement and to consider the accumulated information in exercising its authority.

Perhaps the best illustration of the discretionary approval situation is the Atomic Energy Commission's control over the construction and operation of nuclear power plants. ${ }^{31}$ Although

${ }^{28} 469$ F.2d 593 (10th Cir. 1972).

${ }^{29} \mathrm{Id}$. at 597. The authority of the Department to disapprove a proposed leasing of restricted Indian Lands stems from 25 U.S.C. $\$ 415$, as amended, 25 U.S.C. $\$ 415$ (Supp. III, 1973).

30469 F.2d at 597. Cf. National Forest Preservation Group v. Butz, 485 F.2d 408, 411-12 (9th Cir. 1973): "The land exchange is thus analogous to the licensing of or granting of federal funds to a nonfederal entity to enable it to act. Such federal "enablement' has consistently been held to be subject to NEPA." But see Rucker v. Willis, 484 F.2d 158 (4th Cir. 1973), in which the Army Corps of Engineers was not required to prepare an impact statement before issuing a permit to construct a large commercial pier. Even the dissenting judge thought it obvious that the issuance of a permit by the Corps to a private homeowner would not constitute "major federal action requiring the preparation of an impact statement." Id. at 164 (Craven, J., dissenting). Thus the court was in agreement that some federal permits allowing environmentally adverse private action may be issued without an accompanying impact statement. See also note 63 infra.

${ }^{31}$ See Izaak Walton League v. Schlesinger, 337 F. Supp. 287 (D.D.C. 1971). The Atomic Energy Commission was abolished by the Energy Reorganization Act of 1974, 42 U.S.C.A. $\$ \$ 5801-91$ (Supp., Feb. 1975), and its powers and responsibilities were divided 
the plants are built by private companies, extensive federal regulation has been deemed essential because of planning and safety concerns. Without federal permits the plants can neither be constructed nor operated. Because safety regulation is within the exclusive jurisdiction of the federal agency and because it is not realistic to separate safety from environmental issues, the control of the federal agency over development of nuclear energy facilities mandates that it be held environmentally accountable. Even though the development of a nuclear power plant is technically a private endeavor, regulation of such development places an agency in as proper a position to consider environmental effects as if it actually built the plant. Such an agency may not avoid its environmental responsibilities under NEPA by showing that it did not originally "cause" the power plant to be built. NEPA's directives to federal agencies to consider environmental consequences are broad and must be followed "to the fullest extent possible."

Once it is determined that a project will have significant environmental effects, the question should be not whether the federal financial expenditure is too small, but rather whether the involvement is too slight to justify attributing to the federal agency responsibility for the environmental effects of its action. When the federal government decides whether to fund a project that is environmentally significant under NEPA, it is certainly in a position to exert influence upon the project to the extent that withholding federal funds permits. Focusing on federal responsibility makes it apparent that an impact statement should be required unless the funding is so slight that a denial of funds would not affect the project. ${ }^{32}$

Both Wyoming Outdoor Coordinating Council v. Butz ${ }^{33}$ and Minnesota Public Interest Research Group v. Butz ${ }^{34}$ provide additional support for focusing in this way on federal responsibility. In Wyoming Outdoor Coordinating Council, the Forest Service was ordered to prepare an impact statement before it sold timber from a national forest. Although the court hardly discussed the

between the Energy Research and Development Administration and the Nuclear Regulatory Commission.

${ }^{32}$ See Carolina Action v. Simon, 389 F. Supp. 1244, 1249 (M.D.N.C. 1975), aff'd, Civil No. 75-1253 (4th Cir., June 25, 1975); cf. Jones v. Lynn, 477 F.2d 885, 891 (1st Cir. 1973); Monroe County Conservation Council, Inc. v. Volpe, 472 F.2d 693, 697 (2d Cir. 1972).

${ }^{33} 484$ F.2d 1244 (10th Cir. 1973).

34498 F.2d 1314 (8th Cir. 1974). 
"major federal action" language, there is little doubt that it was strongly influenced by the Forest Service's role as vendor. Such a role is more directly related to the environmental concern at stake than the role of the Department of the Interior in Davis. ${ }^{35}$ Wyoming Outdoor Coordinating Council did not involve mere discretionary approval, but presented a situation in which the federal government affirmatively undertook to engage in an environmentally significant project. The decision to appropriate timber removal areas might not have involved a large federal expenditure, but it placed the federal government in a key position to assess and avoid whatever environmental harm might result. It appears that this key federal position was indeed the basis underlying the court's finding of a major federal action. ${ }^{36}$

Similarly, in Minnesota Public Interest Research Group v. $\overline{B u t z,}{ }^{37}$ the court was unable to base its decision on the amount of the federal expenditure: The "actions of the Forest Service cannot be quantified in terms of dollars to be spent or tons of earth to be moved."38 The court nonetheless determined that the Forest Service was "significantly involved"39 in the timber sales at issue. After the effective date of NEPA the Forest Service negotiated modifications and extensions of the timber sales contracts. Despite this involvement, the court felt obliged to observe that the Forest Service had also made a monetary expenditure when the timber sales failed to generate enough revenue to pay for the subsequent reforestation program. ${ }^{40}$ The financial involvement, however, did not in any way expand the Forest Service's opportunity to respond to the environmental concerns raised by the timber sale and therefore should have been unnecessary to a finding of major federal action.

The Forest Service's activities in Wyoming Outdoor Coordinating Council and Minnesota Public Interest Research Group were instrumental in the execution of the timber sales. In National Helium Corp. v. Morton, ${ }^{41}$ an even simpler question of federal responsibility was posed. There the Secretary of the Interior terminated contracts with suppliers of helium without preparing an impact statement. A direct consequence of the termination

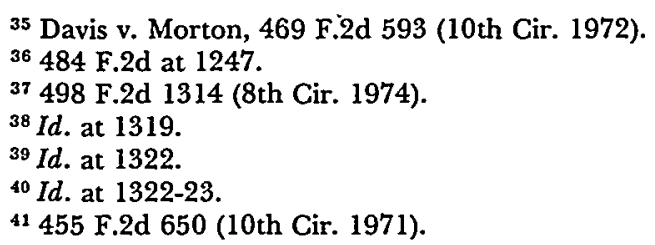


would have been the loss of helium into the atmosphere, accelerating depletion of the country's helium reserves. ${ }^{42}$ The court enjoined termination of the contract, concluding that when federal action is the direct cause of environmental effects, such action is major. This result flowed from an assessment of the degree of federal responsibility for the consequences and not from measurement of the quantitative indicia of federal involvement.

Ostensibly, Scenic Rivers presents a situation of minimal federal involvement and raises the question whether any federal regulatory involvement constitutes major federal action within the meaning of NEPA, rendering primarily private activity susceptible to NEPA's impact statement provision. Although ILSA requires information in the disclosure statement on the availability of sewage facilities for the proposed development, ${ }^{43}$ the primary thrust of the statement is non-environmental. ILSA does not authorize HUD to suspend a development project for any reason other than inaccuracy of the disclosure statement. Even a statement indicating lack of sewage facilities, if accurate, must therefore be approved.

Viewing ILSA on its face, one cannot compare HUD's authority to require accuracy in a disclosure statement with the Department of the Interior's discretionary authority to disapprove a leasing project by the Pueblo Indians, ${ }^{44}$ or with the Forest Service's affirmative involvement in timber sales, ${ }^{45}$ or with Interior's termination of helium supply contracts. ${ }^{46}$ The only benefit of requiring an impact statement in the Scenic Rivers context would be to provide general information for legislative, executive, or public use; the impact statement could not serve as a guide for decisionmaking. Although the informational benefit may be consistent with NEPA's aims, the major federal action requirement demands an initial analysis of HUD's involvement in and responsibility for the environmentally significant development before an impact statement can be required.

${ }^{42} I d$. at 656 .

4315 U.S.C. $\$ 1705(5)(1970)$.

${ }^{44}$ Davis v. Morton, 469 F.2d 593 (10th Cir. 1972); see text accompanying notes 28-30 supra.

45 Wyoming Outdoor Coordinating Council v. Butz, 484 F.2d 1244 (10th Cir. 1973); see text accompanying notes 33-36 supra.

${ }^{46}$ National Helium Corp. v. Morton, 455 F.2d 650 (10th Cir. 1971); see text accompanying notes $41 \& 42$ supra. 
If HUD lacks authority to affect the environmental consequences of a development, it cannot be considered responsible for that development's adverse environmental impact. Because HUD's disapproval of the ILSA statement would hinder or prevent the development project, it might be viewed as a remote link in a chain of causation; ${ }^{47}$ but if HUD cannot disapprove an accurate statement even this causation theory fails. To hold, as Scenic Rivers seems to have done, that any such federal contact is automatically major federal action ${ }^{48}$ is to expand the scope of NEPA far beyond what was contemplated even in the Davis (discretionary authority) case. Both the district and appellate decisions in Scenic Rivers ignore the lack of federal power over the environmental consequences of the proposed development and in effect construe the word "major" out of NEPA. ${ }^{49}$ Scenic Rivers should not have required an impact statement.

The only theoretical justification for the Scenic Rivers decision is that NEPA's phrase "to the fullest extent possible" expands HUD's authority under ILSA to provide for discretionary environmental approval. This issue will be examined below. ${ }^{50}$

\section{B. HUD's Responsibility for Environmental Consequences}

\section{The Two-Pronged Test}

It has been suggested that the "significantly affecting" language and the word "major" in "major Federal actions" represent a single standard. In Minnesota Public Interest Research Group v. Butz, ${ }^{51}$ involving timber sales by the Forest Service, the court expressed concern that " $[\mathrm{b}] \mathrm{y}$ bifurcating the statutory language, it would be possible to speak of a 'minor federal action significantly affecting the quality of the human environment,' and to

${ }^{47}$ See Simmans v. Grant, 370 F. Supp. 5, 14 (S.D. Tex. 1974).

${ }^{48}$ Civil Nos. 74-1520 \& 74-1750 at 9.

${ }^{49} \mathrm{Cf}$. Carolina Action v. Simon, 389 F. Supp. 1244, 1249 (M.D.N.C. 1975), aff'd, Civil No. 75-1253 (4th Cir., June 25, 1975), in which the federal involvement consisted of the provision of funds to a locality under the State and Local Fiscal Assistance Act of 1972 (Revenue Sharing Act), 31 U.S.C. $\$ \$ 1221-1263$ (Supp III, 1973). The district court stated that "[t]he planned use report does not relate to the amount of money to be received and, more importantly, does not entail federal approval of any specific project or confine the discretion of local governments as to the purposes for which the funds should be spent." Civil No. 75-1253 at 12 (footnote omitted). The court held that there was thus no federal action for the purposes of NEPA. But since there was obviously federal action in the lending of funds, the court's real focus must have been on the absence of major federal action.

50 See text accompanying notes 57-88 infra.

${ }^{51} 498$ F.2d 1314 (8th Cir. 1974); see text accompanying notes 37-42 supra. 
hold NEPA inapplicable to such an action." 52 The court felt that such a result would frustrate the intent of NEPA, and that if federal action significantly affected the environment it must have been "major" federal action. This correlation would hold true, if ever, only when the federal action directly and exclusively "caused" the environmental consequences. Otherwise, the court's analysis leaves "major" out of the Act and only looks to the magnitude of the environmental consequences. The court probably thought of "major" and "minor" simply in quantitative terms. If the requirement of major federal action is viewed as a standard of federal responsibility, the court's concern probably would be satisfied.

Other courts have viewed the two phrases as distinct factors for consideration. In Hanly v. Mitchell,,$^{53}$ for example, the Second Circuit articulated the two-pronged approach:

Plaintiffs argue that if a federal action is "major," . . . it must have a "significant" effect on the environment and call for an impact statement. Defendants claim that the term "major Federal action" refers to the cost of the project, the amount of planning that preceded it, and the time required to complete it, but does not refer to the impact of the project on the environment. We agree with defendants that the two concepts are different....54

The two-step analysis conforms more closely to the statutory language; furthermore, the NEPA guidelines promulgated by the Council on Environmental Quality clearly prescribe a multistep approach..$^{55}$

${ }^{52}$ Id. at 1321-22.

53460 F.2d 640 (2d Cir.), cert. denied, 409 U.S. 990 (1972).

${ }^{54} \mathrm{Id}$. at 644 . In Hanly, the plaintiffs tried to argue the converse of the court's position in Minnesola Public Interest Research Group. Instead of saying that a significant effect on the environment implied major federal action, they urged the court to rule that a major federal project involving a large expenditure of funds automatically would have a significant effect on the environment. Id. Although the situations are thus different, and though the latter proposition is logically more difficult to maintain than the former, the Second Circuit's rejection of the unitary standard may also apply to the former situation.

5540 C.F.R. $\S 1500.6$ (c) (1974): "[T] he action must be a (1) 'major" action, (2) which is a 'Federal action,' (3) which has a 'significant' effect, and (4) which involves the 'quality of the human environment.' The words 'major' and 'significantly' are intended to imply thresholds of importance and impact that must be met before a statement is required."

"These CEQ guidelines are merely advisory, because the CEQ does not have the authority to prescribe regulations governing compliance with NEPA." Hiram Clarke Civic Club v. Lynn, 476 F.2d 421, 424 (5th Cir. 1973). 
Part of the difficulty with the Tenth Circuit's decision in Scenic Rivers is that it implicitly adopts a unitary approach and fails to separate the quantitative environmental effects from the nature of federal involvement in the Flint Ridge development. This approach led to the conclusion that any federal action, even review of the accuracy of a real estate disclosure statement, is major federal action. What is implicit in the Tenth Circuit's opinion was explicit in the district court opinion. The latter court found that the Flint Ridge Development Company's projected gross income "reflect[ed] the magnitude of the development and show[ed] that HUD's action in approving the Property Report and Statement of Record under the Interstate Land Sales Act constituted major federal action." 56 The district and appellate courts were reluctant, in light of the finding that the project would have significant environmental effects, to accept that HUD was not responsible in any way for the Flint Ridge Project. If it had taken the bifurcated approach, the court would have been unable to buttress its holding with quantitative financial or environmental data and would properly have been forced to face directly the question of federal responsibility.

\section{The Impact of NEPA on Agency Jurisdiction}

If HUD's power under ILSA were expanded by the operation of NEPA to include discretionary authority to disapprove a development project for environmental reasons, the responsibility analysis discussed above might lead to a finding of major federal action. There is nothing in the Tenth Circuit's opinion in Scenic Rivers to suggest such an expansion. Analogous questions, however, have been raised under other federal statutes.

Section 102 of NEPA directs that federal regulations and laws be "interpreted and administered in accordance with the policies" of the Act "to the fullest extent possible." Judge Skelly Wright, in Calvert Cliffs' Coordinating Committee v. AEC, ${ }^{57}$ wrote that the section 102 duties "must be complied with to the fullest extent, unless there is a clear conflict of statutory authority. Considerations of administrative difficulty, delay or economic cost will not suffice to strip the section of its fundamental importance." 58 The guidelines of the Council on Environmental Quality support Judge Wright's view; "[t]he phrase 'to the fullest

56382 F. Supp. at 72.

s7 449 F.2d 1109 (D.C. Cir. 1971).

${ }^{58} \mathrm{Id}$. at 1115 (footnote omitted). 
extent possible' in section 102 is meant to make clear that each agency of the Federal Government shall comply with that section unless existing law applicable to the agency's operations expressly prohibits or makes compliance impossible." 59

The Army Corps of Engineers' compliance with the spirit of these exhortations was challenged in Zabel $v$. Tabb. ${ }^{60}$ The Corps refused to issue a permit to a mobile home park developer who wanted to dredge and fill valuable tidelands. Although the Corps did not invoke the statutory basis for denial of a permit (obstruction of navigation), the Fifth Circuit upheld the Corps' decision by relying in part on the policies underlying NEPA, although NEPA itself had not been enacted when the Corps' action was taken. ${ }^{61}$ The court held that the Corps was "entitled, if not required, to consider ecological factors" in evaluating permit applications. ${ }^{62}$ The Corps had traditionally been allowed to exercise some discretion in its assessment of projects, and environmental concerns seemed relevant to the Corps' decisionmaking processes. Environmental considerations could be incorporated consistently with the Corps' existing authority. Though the Corps employed NEPA to justify its own decision, the result might be the same when concerned citizens seek an impact statement, once the Corps' discretionary authority is deemed to include environmental factors. When significant environmental effects may be foreseen, the Corps' ability to respond effectively to such factors in making a permit decision should render its decision major federal action. ${ }^{63}$

Some courts, however, take a narrower view of the authority granted by NEPA. In Kitchen $v . F C C,{ }^{64}$ for example, residents of a community in which the telephone company proposed to con-

5940 C.F.R. $\$ 1500.4(a)$ (1974).

60430 F.2d 199 (5th Cir. 1970), cert. denied, 40 I U.S. 910 (1971).

$61430 \mathrm{~F} .2 \mathrm{~d}$ at 213.

${ }^{62}$ Id. at 201 .

${ }^{63}$ An argument can be made that this type of decision by a federal agency should never be subject to NEPA's impact statement requirement. The language of the statute refers to inclusion of an impact statement in every "recommendation" or "report" on "proposals for legislation" or "other major Federal actions." Because processing of permit or license applications or approval of private projects (as by HUD under ILSA) may not involve the preparation of a report on proposed federal action, because the action proposed is private, $\S 102(2)(\mathrm{C})$ may be wholly inapplicable to this kind of administrative action. $C f$. Anderson, supra note 1 , at 125-26.

64464 F.2d 801 (D.C. Cir. 1972). Cf. Transcontinental Gas Pipe Line Corp. v. Hackensack Meadowlands Dev. Comm., 464 F.2d 1358 (3d Cir. 1972), cert. denied, 409 U.S. 1118 (1973). 
struct an exchange building argued that NEPA required the Federal Communications Commission to consider the environmental effects of the construction. The Communications Act denied the FCC jurisdiction over the telephone exchange building, which was regulated by the state; ${ }^{65}$ the Commission could not approve or disapprove construction on any grounds. The court agreed with the FCC and the telephone company that NEPA may supplement existing agency authority but cannot confer new jurisdiction on the agency. ${ }^{66}$

In Gage v. $A E C,{ }^{67}$ farmers whose land was about to be acquired for a nuclear power plant site, by the exercise of eminent domain, sought to require the Atomic Energy Commission to prepare an impact statement before any land was taken. The court noted, besides the practical difficulty of having the AEC prepare a statement before being approached for a permit, that "NEPA does not mandate action which goes beyond the agency's organic jurisdiction." 68

A seemingly contrary case, National Resources Defense Council v. Morton ${ }^{69}(N R D C)$, is distinguishable. There the Department of the Interior was ordered to look beyond the scope of its immediate authority in making a decision about the leasing of offshore oil and gas tracts. The Department sought to avoid consideration of the elimination of oil import quotas as an alternative to leasing the tracts, because it believed that such an inquiry was beyond the scope of its expertise and decisionmaking authority. ${ }^{70}$ Of course, one of the most important elements of an impact statement is the discussion of "alternatives to the proposed action." 71 The court required the consideration of oil import quotas, but did so on quite narrow grounds: "While the Department of the Interior does not have the authority to eliminate or reduce oil import quotas, such action is within the purview of both Congress and the President, to whom the impact statement goes." 72 The court recognized the benefit to be derived from consolidating pertinent information into one statement that would inform executive and legislative decisionmak-

\footnotetext{
${ }^{65}$ Communications Act $\$ 221$ (b), 47 U.S.C. $\$ 221$ (b) (1970); see 464 F.2d at 802-03.

${ }^{66} 464$ F.2d at 802.

67479 F.2d 1214 (D.C. Cir. 1973).

${ }^{68} \mathrm{Id}$. at 1220 n.19.

69458 F.2d 827 (D.C. Cir. 1972).

${ }^{70} \mathrm{Id}$. at 834 .

${ }^{71} 42$ U.S.C. $\S 4332(2)$ (C) (iii) (1970).

${ }^{72} 458$ F.2d at 835 .
} 
ers. $N R D C$ is unique in that it involved the development of a comprehensive plan to deal with the impending energy crisis, thus broadening the Department's duties to evaluate alternatives. ${ }^{73}$ Most important, the Department did not dispute its obligation to file an impact statement, but only defended as adequate the statement it had already filed, ${ }^{74}$ which did not contain a discussion of the environmental impact of alternatives. The content of the statement, not its necessity, was at issue.

The Interstate Land Sales Act is legislation of specific purpose and restricted scope. ${ }^{75}$ Congressional concern was limited to protection of the real estate buyer. HUD has discretion only in determining whether disclosure has been adequate. "Ordinarily, when an agency is granted discretionary authority, that discretion is to be exercised within certain limits and for the accomplishment of certain statutory purposes."76 NEPA's general policies of disclosure and agency concern for the environment should not be interpreted to expand HUD's powers to enable it, in effect, to prevent real estate sales because of potential environmental problems.

For HUD to consider environmental effects when deciding whether to approve ILSA disclosure statements would conflict with its statutory authority. Because HUD has no power to prevent sales on environmental grounds, requiring the preparation of an impact statement would be a serious waste and misallocation of agency resources. Impact statements are designed, in part, to influence agency decisions; when the decisionmaker cannot take the environment into account, NEPA is not frustrated by the lack of an impact statement. ${ }^{77}$

Although it cannot prevent sales because it disapproves of the environmental consequences, and should not be required to

${ }^{73} \mathrm{Id}$.

${ }^{74}$ See id. at 829.

${ }^{75}$ See notes 9-14 supra \& accompanying text.

is Crampton \& Berg, On Leading a Horse to Water: NEPA and the Federal Bureaucracy, 71 Mich. L. Rev. 511, 520 (1973).

7 Even the size of the ILSA application fee supports this interpretation. Careful preparation of a complete and detailed impact statement is an expensive undertaking, but the maximum fee that can be charged is a thousand dollars. 15 U.S.C. $\$ 1704$ (b) (1970). The purpose of the fee is to "cover all or part of the cost" incurred by HUD. Id. Congress intended the program to be essentially self-supporting; to require preparation of impact statements would defeat the clear congressional purpose. Furthermore, HUD could not rely solely on information supplied by the developer and would have to undertake a detailed study of its own. Greene County Planning Bd. v. FPC, 455 F.2d 412 (2d Cir.), cert. denied, 409 U.S. 849 (1972); accord, Conservation Soc'y v. Secretary, 508 F.2d 927 (2d Cir. 1974). 
prepare an impact statement, HUD does have a significant responsibility under NEPA. The environmental disclosure policies of NEPA are designed not only to benefit officials in government, but also to assist the public in its decisionmaking. ${ }^{78}$ The reasonable real estate investor can be expected to want to know about the environmental consequences of the development in which he may invest. Perhaps the natural beauty of the area has led him to invest his money; adverse environmental consequences from the development could frustrate his purposes.

The analogy to the Securities and Exchange Commission, ${ }^{79}$ which administers the Securities Act of $1933,{ }^{80}$ is instructive. One of the purposes of that act is disclosure of information about a corporation needed by the investor. The SEC has developed regulations that require disclosure of certain environmental matters. ${ }^{81}$ In Natural Resources Defense Council v. $S E C,{ }^{\mathbf{8 2}}$ plaintiffs sought to have the SEC broaden the disclosure regulation to cover the effect of corporate activities on the environment. In remanding to the SEC for further rulemaking proceedings, the court mentioned the SEC's "broad rulemaking authority," which enables it to require "information which a reasonable investor might have considered important in making an investment decision." 83 The congressional mandate to the federal agencies contained in NEPA is "superimposed" upon the SEC's rulemaking authority: "NEPA gives specific content to the SEC's authority under the securities laws to require disclosure of information "in the public interest." "84

To fulfill its duty to effectuate the policies of NEPA "to the fullest extent possible," HUD should demand extensive disclosure of the environmental consequences of a proposed development. Because of his personal relationship to the land purchased, the buyer of real estate will be even more concerned than the investor in corporate securities about the environmental aspects of the investment. The Interstate Land Sales Act directly

${ }^{78}$ Cf. Calvert Cliffs' Coordinating Comm. v. AEC, 449 F.2d 1109 (D.C. Cir. 1971).

${ }^{79}$ See note 11 supra.

8015 U.S.C. $\$ \S 77$ a-aa $(1970)$.

81 The SEC regulations require disclosure of the corporation's environmental litigation and the effect on the corporation's financial condition of its compliance with environmental laws and regulations. SEC Securities Act of 1933 Release No. 5386 (Apr. 20, 1973).

82389 F. Supp. 689 (D.D.C. 1974).

${ }^{83} \mathrm{Id}$. at 695 .

84 389 F. Supp. at 695. 
mandates disclosure of some environmental information..$^{85}$ The Secretary of Housing and Urban Development is empowered to promulgate regulations to carry out his mission of enforcing the Act. ${ }^{86}$ With the NEPA mandate added to this authority, there should be no doubt about his power to expand the scope of disclosure required in the statement of record. Because HUD can investigate the accuracy of the information provided ${ }^{87}$ and seek severe penalties for untrue statements or omissions of material facts, ${ }^{88}$ the information most likely will be accurate. By adopting this approach, HUD would remain within its jurisdictional limits and would accomplish a fundamental goal of NEPA, disclosure of environmental information.

\section{Conclusion}

In order to determine what is major federal action under NEPA, it is recommended that courts focus their inquiry on the federal responsibility for actions that portend a significant environmental impact. Federal responsibility cannot be found when the federal agency lacks the authority to disapprove or modify a proposed project on environmental grounds. In Scenic Rivers HUD was bound by ILSA to approve an accurate and complete disclosure statement and possessed no discretionary authority to alter or impede the development because of potential pollution hazards. NEPA's mandate that "to the fullest extent possible" federal regulations and laws "be interpreted and administered in accordance with the policies set forth in [NEPA]" does not provide a basis for expansion of the agency's statutory authority. HUD was not responsible for the development's potential environmental effects, and thus major federal action should not have been found.

As the court directed in Hanly v. Mitchell, ${ }^{89}$ the inquiry into whether a proposed project involves significant environmental effects must be kept separate from the question of the degree of federal action. A project may threaten significant environmental impact but not involve the federal government enough to trigger

${ }^{85} 15$ U.S.C. $\S 1705(5)(1970)$.

${ }^{86} 15$ U.S.C. $\$ 1718$ (1970). The current regulations for the Office of Interstate Land Sales Regulation are set forth at 24 C.F.R. $\$ \S 1700.1-1720.530$ (1975).

${ }^{87} 15$ U.S.C. $\$ 1714$ (b) (1970).

${ }^{88} 15$ U.S.C. $\$ 1717$ (1970).

${ }^{89} 460$ F.2d 640 (2d Cir.), cert. denied, 409 U.S. 990 (1972); see text accompanying notes 53-55 supra. 
the impact statement requirement. The district and appellate courts in Scenic Rivers seem to have based their finding of major federal action in part on the magnitude of the overall project and its potentially adverse environmental impact. The courts ignored HUD's inability to avert that impact.

Environmental impact disclosure regulations that place the burden of predicting a development's environmental consequences on the developer should, however, be adopted by HUD in administering ILSA. A land development's effect on the environment may be a significant consideration in a decision to purchase. But even with such regulations, HUD's actions under ILSA should not require the preparation of an environmental impact statement. 